\title{
Prevalence of Smoking Among Employees of a University Hospital
}

\author{
Isabel Cristina Echer ${ }^{1}$ \\ Ana Paula Almeida Corrêa ${ }^{2}$ \\ Amália de Fátima Lucena $^{3}$ \\ Stephani Amanda Lukasewicz Ferreira ${ }^{2}$ \\ Marli Maria Knorst ${ }^{4}$
}

\begin{abstract}
This cross-sectional study aimed to identify the prevalence of smoking among employees of a university hospital in Southern Brazil. Data collection happened in 2008, during the periodic health exam, using a questionnaire, according to the smoking status of the employees. The sample consisted of 1,475 subjects, in which 979 (66.4\%) were non-smokers, 295 (20\%) former smokers and 201 (13.6\%) smokers. Smoking was more prevalent among employees with lower education levels and among professionals in administrative positions. Among smokers, low dependence was identified, as well as desire and high degree of motivation to stop smoking, with health concerns as the main reason. Thus, taking into account the motivation of smokers to stop smoking, this is an appropriate time for health education and specific support to employees in the process of smoking cessation.
\end{abstract}

Descriptors: Prevalence; Occupational Health; Tobacco Use Cessation.

\footnotetext{
${ }^{1}$ RN, Ph.D. in Medical Sciences, Adjunct Professor, Escola de Enfermagem, Universidade Federal do Rio Grande do Sul, RS, Brazil. E-mail: isabel.echer@terra.com.br.

${ }^{2}$ Nursing undergraduate student, Escola de Enfermagem, Universidade Federal do Rio Grande do Sul, RS, Brazil. E-mail: Ana Paula anacorrea@hotmail.com, Stephani - tekinha_amanda@hotmail.com.

${ }^{3}$ RN, Ph.D. in Sciences, Adjunct Professor, Escola de Enfermagem, Universidade Federal do Rio Grande do Sul, RS, Brazil. E-mail: fatimalucena@terra.com.br.

${ }^{4}$ Physician, Ph.D. in Medical Sciences, Associate Professor, Faculdade de Medicina, Universidade Federal do Rio Grande do Sul, RS, Brazil. E-mail: mknorst@hcpa.ufrgs.br.
}

Corresponding Author:

Isabel Cristina Echer

Universidade Federal do Rio Grande do Sul. Escola de Enfermagem.

Rua São Manoel, 963 - Campus Saúde

Bairro Rio Branco

CEP: 90620-110 Porto Alegre, RS, Brasil

E-mail: iecher@hcpa.ufrgs.br 


\section{Prevalência do tabagismo em funcionários de um hospital universitário}

Este é um estudo transversal, e teve como objetivo identificar a prevalência do tabagismo em funcionários de um hospital universitário do Sul do Brasil. A coleta de dados ocorreu no ano 2008, durante exame periódico de saúde dos funcionários, por meio de questionário, de acordo com a condição tabágica dos mesmos. A amostra ficou constituída por 1.475 sujeitos, desses, 979 (66,4\%) eram não fumantes, 295 (20\%) exfumantes e $201(13,6 \%)$ fumantes. O predomínio de fumantes está entre funcionários com menor nível de instrução e entre aqueles que exerciam atividades em cargos administrativos. Identificou-se, entre os fumantes, dependência leve, desejo e grau de motivação elevados para cessar o tabagismo, sendo o principal motivo a preocupação com a saúde. Assim, considerando-se a motivação dos funcionários para parar de fumar, recomenda-se aproveitar esse momento para realizar trabalho de educação em saúde e apoio profissional específico, para que o processo de cessação do tabagismo ocorra.

Descritores: Prevalência; Saúde do Trabalhador; Abandono do Uso de Tabaco.

\section{Prevalencia del tabaquismo en funcionarios de un hospital universitario}

Estudio transversal con objetivo de identificar a prevalencia del tabaquismo en funcionarios de un hospital universitario del sur de Brasil. La recolección de datos ocurrió en el año de 2008, durante el examen periódico de salud de los funcionarios, por medio de cuestionario de acuerdo con la condición de fumador de los mismos. La muestra se constituyó de 1.475 sujetos, de estos 979 (66,4\%) no fumaban, 295 (20\%) ex-fumantes y $201(13,6 \%)$ fumantes. El predominio de fumantes está entre funcionarios con menor nivel de instrucción y entre los que ejercían actividades en cargos administrativos. Se identificó entre los fumantes, dependencia leve, deseo y grado de motivación elevado para cesar el tabaquismo, siendo el principal motivo la preocupación con la salud. Así, considerándose la motivación de los funcionarios para parar de fumar, se recomienda aprovechar este momento para realizar un trabajo de educación en salud y de apoyo profesional específico para que el proceso de cesación del tabaquismo ocurra.

Descriptores: Prevalencia; Salud Laboral; Cese del Uso de Tabaco.

\section{Introduction}

Smoking is the main avoidable cause of death around the world. Data appoint prevalence levels of one third of smokers in the global adult population, i.e. about 1 billion and 200 million smokers ${ }^{(1)}$.

Tobacco causes health-related problems, considering high morbidity and mortality rates due to cancer, cardiovascular, cerebrovascular and respiratory illnesses, representing a challenge not only for health services, but also for economic, social and environmental development ${ }^{(2-3)}$.

When smoking, people inhale about 4,700 substances, including nicotine, carbon monoxide, tar, pesticides and radioactive substances. Nicotine causes addiction, enhancing the negative effects of cigarette smoke components and increasing the risk of diseases $^{(4)}$. Tobacco is responsible for the death of 4.9 million people per year around the world, i.e. about 10 million deaths per day. If consumption trends continue, statistics reveal that, by 2030 , this figure will double, reaching 10 million people ${ }^{(5)}$.

Data from the Brazilian Institute for Geography and Statistics for 2008 show that $17.5 \%$ of people aged 15 years or older are smokers, corresponding to 25 million in total. In Brazil, the highest percentage is found in the South, with $19 \%{ }^{(6)}$. 
Law No 9.294, issued in 1996, prohibits the use of any tobacco-derived smoke-producing agent in private or public collective rooms, except in places specifically destined for this purpose. Interministerial decree No 1.498, issued in 2002, recommends that health and teaching institutions set up programs for rooms free from environmental tobacco exposure(7). In São Paulo State, a law was recently approved which prohibits smoking in closed environments for collective use, such as bars, restaurants, nightclubs and other commercial establishments. Smoking lounges in work environments and in smoking areas in restaurants were also prohibited ${ }^{(8)}$. These measures have contributed to a decline in tobacco use ${ }^{(9)}$.

Information campaigns, in turn, are still insufficient to promote a political, cultural and social change related to smoking behavior. Besides, interventions to interrupt tobacco use are not integrated into health service routines due to different factors, such as lack of available time to add more specific care actions and some health professionals' perception that nicotine addiction treatments are hardly effective ${ }^{(4,10)}$.

In view of the fact that smoking entails health problems and that hospitals are spaces for preventing and treating this problem, the goal is to identify the prevalence of smoking among workers of a university hospital in Southern Brazil, with a view to creating spaces for in-depth discussions on health promotion and developing programs and interventions for health workers, so as to inhibit the start of smoking and promote cessation.

\section{Methods}

This cross-sectional study was carried out at a teaching hospital in Southern Brazil, where multiple care is delivered, oriented towards care delivery, teaching and research. The population comprised hospital employees $(4,100$ people), including all professional categories.

Based on an earlier study(11), the minimum sample size was calculated at 1,154 employees, with a $2 \%$ error margin and a $98 \%$ confidence level. In total, 1,475 employees were included in the sample, however.

Data were collected between January and December 2008, during the workers' periodical health check-up at the hospitals' Occupational Medicine Service. The research was disseminated at the institution and the invitation to take part was highlighted among the employees before the consultation. For those who agreed to participate, the research aims were explained and questions were asked about their smoking condition, i.e. whether they were non-smokers, former smokers or smokers, so as to choose what questionnaire to apply. Non-smokers were considered people who had never smoked and/or had only tried smoking, but did not turn into a smoker; former smokers were people who had regularly smoked but had not smoked in the last six months (in this study, the term former smoker is used to indicate smokers who abstained from smoking); and smokers, meaning people who regularly smoke one or more cigarettes per day. Each employee answered only one questionnaire according to his/her smoking condition and then placed it in a sealed and unidentified envelope.

The questionnaires contained questions about active and passive smoking, nicotine addiction, smokingassociated illnesses, motivation to quit smoking or continue smoking and socio-demographic data.

Inclusion criteria were: being a hospital employee, agreeing to fill out the research questionnaire and age of 18 years or older. Employees who did not complete the questionnaire at the time of the periodical check-up were excluded and refused to participate in research.

For the smoking group, nicotine addiction was assessed through the Fagerström ${ }^{(12)}$ score, which ranks smokers' dependence as follows: 0-2 points = very low dependence; 3-4 points = low dependence; 5 points $=$ medium dependence; $6-7$ points $=$ high dependence and 8-10 points $=$ very high dependence. Smokers degree of motivation to quit smoking was also assessed, in which zero means no motivation and 10 maximum motivation.

Data were analyzed through descriptive statistics, with the help of Statistical Package for the Social Sciences software version 16. Pearson's Chi-Square Test, Fisher's Exact Test and logistic regression were applied. Any association and difference with $p<0.005$ was considered statistically significant. Percentages displayed are based on valid answers, as employees did not complete some questions.

Approval for the research project was obtained from the Hospital's Institutional Review Board under No 07010. Returning the completed questionnaire formalized the subject's consent to participate in the study. Secrecy was guaranteed, as well as information use solely for research purposes and the right to cease participating at any time.

\section{Results}

Study participants were 1,475 employees (35.9\% of hospital staff), including 1,049 (71.2\%) women. Among the participants, 979 (66.4\%) were nonsmokers, 295 (20\%) former smokers and 201 (13.6\%) smokers (Table 1). 
Table 1 - Association between socio-demographic variables and groups of non-smokers, former smokers and smokers. Porto Alegre, RS, 2010

\begin{tabular}{|c|c|c|c|c|c|}
\hline & & & Groups & & \\
\hline Variable & & & Former smoker & Smoker & $\mathbf{p}$ \\
\hline Gender & & & & & 0.732 \\
\hline Female & $1049(71.2)$ & $690(70.6)$ & $214(72.5)$ & $145(72.5)$ & \\
\hline Male & $424(28.8)$ & $288(29.4)$ & $81(27.5)$ & $55(27.5)$ & \\
\hline Total & $1473(100)$ & $978(66.4)$ & $295(20)$ & $200(13.6)$ & \\
\hline Mean age (years) & - & 42 & 45 & 44 & $<0.001$ \\
\hline Education level & & & & & $<0.001$ \\
\hline Primary education & $126(8.5)$ & $60(6.1)$ & $36(12.2)$ & $30(14.9)$ & \\
\hline Secondary education & $649(44.0)$ & $411(42.0)$ & $133(45.1)$ & $105(52.2)$ & \\
\hline Higher education and post-graduation & $700(47.5)$ & $508(51.9)$ & $126(42.7)$ & $66(32.8)$ & \\
\hline Total & $1475(100)$ & $979(66.4)$ & $295(20)$ & $201(13.6)$ & \\
\hline Professional activity & & & & & 0.027 \\
\hline Care & $848(57.6)$ & $583(59.7)$ & $165(55.9)$ & $100(49.8)$ & \\
\hline Administration & $624(42.4)$ & $393(40.3)$ & $130(44.1)$ & $101(50.2)$ & \\
\hline Total & $1472(100)$ & $976(66.3)$ & $295(20)$ & $201(13.7)$ & \\
\hline Work hours & & & & & 0.265 \\
\hline Day & 1159 (78.6) & 765 (78.1) & $238(80.7)$ & $156(77.6)$ & \\
\hline Night & $272(18.4)$ & $180(18.4)$ & $49(16.6)$ & $43(21.4)$ & \\
\hline On call & $44(3.0)$ & $34(3.5)$ & $8(2.7)$ & $2(1.0)$ & \\
\hline Total & $1475(100)$ & $979(66.4)$ & $295(20)$ & $201(13.6)$ & \\
\hline Smoking-related illness & & & & & 0.008 \\
\hline Yes & $278(18.9)$ & $167(17.1)$ & $74(25.2)$ & $37(18.5)$ & \\
\hline No & $1191(81.1)$ & $808(82.9)$ & $220(74.8)$ & $163(81.5)$ & \\
\hline Total & $1469(100)$ & $975(66.4)$ & $294(20)$ & $200(13.6)$ & \\
\hline Contact with smokers & & & & & 0.320 \\
\hline Yes & $563(44.3)$ & $425(43.5)$ & $138(46.8)$ & - & \\
\hline No & $709(55.7)$ & $552(56.5)$ & $157(53.2)$ & - & \\
\hline Total & $1272(100)$ & $977(76.8)$ & $295(23.2)$ & - & \\
\hline
\end{tabular}

The association between smoking situation (nonsmoker, former smoker and smoker) and variables like gender, age, education level, type of professional activity, work hours and presence or absence of smoking-associated illnesses was assessed. A significant difference $(p<0.001)$ between the three groups was observed, with the lowest mean score in the group of non-smokers. Likewise, education levels significantly differed among the three groups $(p<0.001)$, with a higher level among non-smokers.

In the association between professional activity and smoking condition $(p=0.027)$, prevalence levels of non-smokers were higher among participants in care functions, and on smokers among participants in administrative functions. No association was found between gender and work shift and smoking condition $(p>0.005)$. Contact with smokers did not vary between non-smokers and former smokers $(p=0.320)$.

As for the presence of smoking-associated illnesses, $278(18.9 \%)$ employees informed this, more frequently in the group of former smokers $(p=0.008)$. The main illnesses the participants indicated were: circulatory, 124 (8.4\%); respiratory, 99 (6.7\%); psychiatric, 17 $(1.1 \%)$; and gastrointestinal, $17(1.1 \%)$. The analysis of the relation between the presence of illnesses and the smoking condition showed an upward trend in circulatory diseases in the group of former smokers, although not statistically significant.

In multivariate logistic analysis, the factors associated with the smoking condition also were age and education level $(p<0.001)$.

The comparison between former smokers and smokers' smoking pattern disclosed differences in the duration of tobacco consumption $(p<0 / 001)$. No significant variation was found in the number of cigarettes consumed per day $(p=0.603)$ in both groups of individuals, nor in the start age of smoking $(p=0.039)$ (Table 2). 
Table 2 - Association between variables related to smoking in the group of smokers and former smokers. Porto Alegre, RS, 2010

\begin{tabular}{lcccc}
\hline \multirow{2}{*}{\multicolumn{1}{c}{ Variable }} & \multicolumn{2}{c}{ Groups } & \\
\cline { 2 - 3 } & $\begin{array}{c}\text { Former } \\
\text { smokers }\end{array}$ & & Smokers & p \\
\cline { 2 - 2 } & Mean \pm SD & & Mean \pm SD & \\
\hline $\begin{array}{l}\text { Start age of smoking (years) } \\
\begin{array}{l}\text { Number of cigarettes smoked } \\
\text { (day) }\end{array}\end{array}$ & $17.7 \pm 4.6$ & & $18.6 \pm 4.8$ & 0.039 \\
$\begin{array}{l}\text { Duration of tobacco } \\
\text { consumption (years) }\end{array}$ & $14.2 \pm 9.6$ & & $23.6 \pm 9.9$ & $<0.001$ \\
\hline
\end{tabular}

SD: standard deviation

In an adjusted model, the assessment of the start age of smoking in years (OR=1.12;95\% CI: $1.07 ; 1.18)$ and duration of tobacco consumption in years $(\mathrm{OR}=1.12$; $95 \% \mathrm{CI}: 1.09 ; 1.14)$ revealed that these two variables are associated with the fact of being a smoker.

Smokers were asked about their position towards smoking cessation. Forty-one people (21\%) mentioned that they were not planning to give up smoking in the next six months, $52(26.7 \%)$ said they were motivated to quit smoking in the next six months, $27(13.8 \%)$ intended to quit smoking during the next month and 70 (35.9\%) had quit smoking but suffered a relapse, while $11(2.6 \%)$ did not answer this question.

The smokers' nicotine addiction was analyzed through the Fagerström Scale(12). It is highlighted that $122(61 \%)$ demonstrated a very low nicotine dependence level (0-2 points), 44 (21.9\%) low dependence (3-4 points), 10 (4.9\%) medium dependence ( 5 points), 19 (9.7\%) high dependence (6-7 points) and $5(2.4 \%)$ very high dependence (8-10 points). Regarding the smokers' willingness to quit smoking, 157 (78.5\%) gave an affirmative answer, while 43 (21.5\%) do not want to stop.

The average motivation to quit smoking, on a scale from 0 to 10 , reached $5.6( \pm 3)$ (Figure 1$)$. Fifty-one professionals (26.4\%) scored an average five points on the scale of motivation to quit smoking, while 32 (16.6\%) scored eight points. Twenty-one (10.9\%) professionals demonstrated the maximum level of motivation to quit smoking (10 points) and $31(16.6 \%)$ were not motivated (0 points).

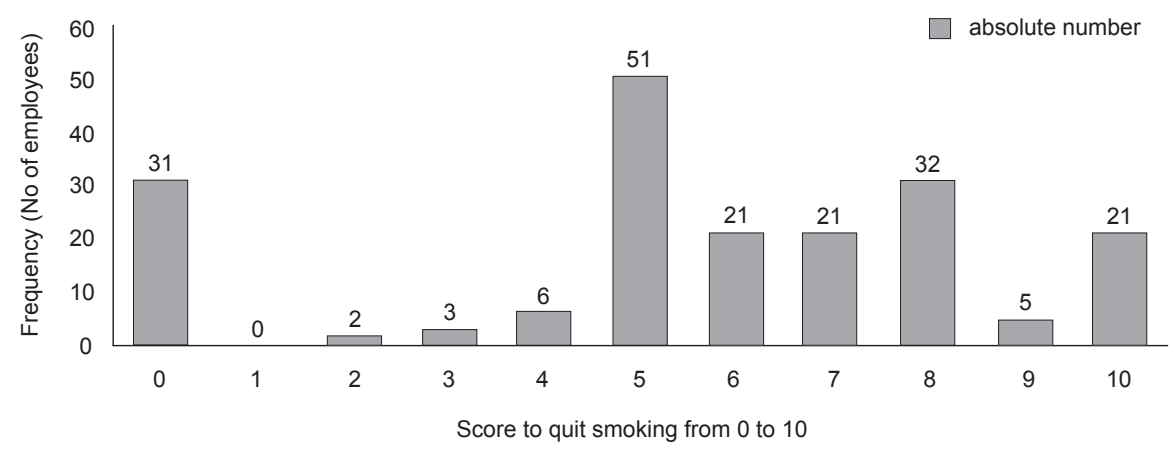

Figure 1 - Scale of motivation to quit smoking. Porto Alegre, RS, 2010

The reasons people willing to quit smoking appointed were: concern with health, 54 (34\%); knowledge about the harmful effect of tobacco, 29 (18\%); influence from loved ones, 14 (9\%); harmful effects for health, $16(10 \%)$; quality of life, $14(9 \%) ;$ and others 30 $(19 \%)$, including shame of the smell, financial issues, serving as an example for other smokers to quit, pregnancy, smoking-related death among relatives or friends, working in an environment where smoking is prohibited.

The main factors for not quitting were lack of will, $11(26 \%)$; difficulty in the abandonment process, 9 (21\%); small number of cigarettes smoked, 7 (16\%); satisfaction when smoking, 7 (16\%); and others, 9
$(21 \%)$, such as not wanting to feel abstinence symptoms, denying addiction and not accepting cigarettes as a health threat.

\section{Discussion}

The average age of most women in the study sample was 43 years. The predominance of women is due to the fact that the study area is the nursing department of a health institution, a profession that joins a large number of women. Similar results were also found in other studies ${ }^{(13)}$. What is important, however, is the fact that gender is not a determinant variable for the habit of smoking or not. 
The prevalence of smoking at the institution was $13.6 \%$, lower than in Brazil, where $17.5 \%$ of people over 15 years of age are smokers, and in the South, where $19 \%$ of the population smokes nowadays ${ }^{(6)}$. This percentage may be related to the prohibition of smoking at the workplace and the fact that smoking workers need to go to specific places for this practice, temporarily leaving their activities aside, which is not always possible. Although lower than other levels, however, this percentage cannot be ignored, as the population comprises health professionals.

A significant difference was identified between mean age and the group of former smokers (45 years) and non-smokers (42 years) $(p<0.001)$. Some studies appoint the highest concentration of smokers between 20 and 49 years of age ${ }^{(14)}$. Although the difference is significant, the groups' mean age was about 43 years. In other words, participants were young and fully active in professional terms.

Smokers and former smokers have a lower education level, in accordance with studies revealing that years of formal education influence the lesser probability of starting to or keeping up smoking(15-16). More years of education may enhance greater awareness on the harm smoking can cause and the benefits of not smoking, which is why individuals with higher education levels avoid smoking.

No difference was found between non-smokers, former smokers and smokers and the work shift. Among workers from an industry, little association was also verified between risk behavior for health, such as smoking, and work hours ${ }^{(15)}$.

Most employees informed no smoking-associated illnesses and, when present, these were more frequent among non-smokers. In this group, an upward trend in cardiovascular diseases was observed. A similar result was found in a study of patients diagnosed with cardiac arrest ${ }^{(17)}$, based on which it can be inferred that the presence of illnesses can positively affect the abandonment of smoking, due to knowledge about the possible aggravation of their health condition due to the harmful effects of smoking. Thus, health professionals should encourage smokers to quit smoking before their health is compromised and not afterwards.

The mean start age of tobacco consumption was approximately 18 years, similar to other studies that demonstrate that tobacco consumption starts during

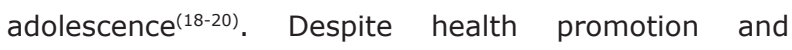
prevention campaigns that raise awareness on the harmful effects of cigarettes, it is known that, until today, tobacco is an instrument of curiosity and self-assertion among young people. The stereotype of breaking rules, of the prohibited, the feeling of freedom still attracts many adolescents into experimenting cigarettes and, often, into addiction.

No significant difference was found in the number of cigarettes smoked between former smokers and smokers. This fact can stimulate those who have not quit smoking yet, as people who on the average consumed the same number of cigarettes per day became former smokers, which means that they too can manage to change their condition.

In $82.9 \%$ of smokers, nicotine dependence was low or very low and, to a lesser extent, high or very high. Although most professionals mentioned low nicotine dependence, which presupposes less difficulty in the smoking cessation process, one group showed greater dependence. These individuals can benefit from professional follow-up and medication use, with a view to facing the abstinence syndrome with less suffering(4).

It was evidenced that care professionals smoke less than administrative workers. What probably explains this difference is the fact that prohibiting smoking in the workplace temporarily removes smokers from their activities in order to smoke at a specific place, which is not always possible in the hospital care routine. For administrative professionals, on the other hand, it is easier to get away from work tasks to smoke in the hospital's smoking lounges, considering that, in most cases, they are not directly involved with patients. Other studies found similar results, appointing higher prevalence levels of smokers among professionals from other areas than among professionals graduated or working in the health area(16,19). These may smoke less because they are more aware of the problems deriving from tobacco consumption than other professionals and/ or also because they have contact with patients with health problems associated with smoking, besides the severe restrictions on smoking in these environments.

When comparing the duration of smoking between former smokers and smokers, it was verified that workers who managed to quit smoked less time. This finding suggests that consumption time can negatively influence smoking abandonment and that nicotine dependence can increase with consumption time. This can be associated with the fact that smokers experience more difficulty to quit smoking because they have smoked longer and, therefore, are more dependent.

Regarding the motivation to quit smoking, it is highlighted that $36 \%$ of smokers have attempted 
several times to quit, but have experienced relapses. A study among health professionals reveals that about $80 \%$ of them have already attempted several times to give up tobacco(18). This shows that, although people are motivated to quit smoking, this process can be difficult, requiring professional help and an intensive approach towards chemical and psychological dependence on cigarettes.

The main reasons mentioned to quit smoking included health concerns, knowledge about the harmful effects of tobacco and influence from loved ones. Other researchers also mention that most would like to give up smoking and reduce consumption. They appoint the individual's will/determination, but also influence from other people, such as professionals, relatives, friends and social communication means and smoking regulations ${ }^{(9,21)}$.

This reinforces the idea that the motivation to change involves multiple factors and occurs differently for each individual, involving not only his/her will, but also the context and moment of life. Therefore, when monitoring smokers, it is fundamental to identify their motivation to quit smoking, as well as the existence or not of a social support network, as more effective intervention strategies.

The factors appointed as reasons not to quit smoking include lack of will to quit smoking, pleasure of smoking and the difficulty of the abandonment process. Literature also lists the feelings of pleasure, stress relief and habit among the main reasons that prevent people from giving up smoking ${ }^{(16)}$. The main reasons the smokers appointed not to quit smoking are linked with chemical addiction to nicotine, which is the main responsible for cessation difficulties. This point underlines these people's need for monitoring by health professionals who are trained to facilitate the abandonment process, so that it can actually happen.

There are some limitations to this study, such as the fact that the participants' data were collected through an instrument they answered themselves, according to their perspective, which can be influenced by some factors, such as lack of memory or even denial of the actual data. These participants' assessments by health professionals could add information and permit the design of appropriate intervention strategies to address smoking. Another limitation was the voluntary participation, which may have underestimated the number of smokers, as this was nor confirmed through biological measures. This may have biased the proportion of the study groups.

\section{Conclusions}

Smoking prevalence at the institution was lower than rates in Brazil, Rio Grande do Sul and Porto Alegre, possibly due to the fact that smoking is strictly prohibited in the hospital environment, besides the fact that health professional have greater access to information on the consequences of smoking for the organism.

The highest prevalence levels of smokers exist among administrative workers and professionals with lower education levels, based on which it can be inferred that those working in direct patient care and with more years of education have more knowledge on the benefits of not smoking for health.

Most smokers revealed their willingness and motivation to quit smoking, demonstrating the importance of using this moment, through specific programs, to help them quit. This becomes even more important in view of the fact that they work for an institution that aims to promote, prevent and restore health.

In view of the above, this knowledge is considered relevant for the elaboration of educational health intervention programs, especially conceived for this group, with a view to contributing to workers' wellbeing and health and, hence, their quality of life.

\section{References}

1. Ministério da Saúde (BR). Instituto Nacional do Câncer. Tabagismo: dados e números. Rio de Janeiro: INCA; 2008. [acesso 20 jul 2009]; Disponível em: http://www.inca.gov.br/tabagismo/frameset. asp?item $=$ dadosnum\&link = mundo. htm .

2. Machado VC, Alerico MI, Sena J. Programa de prevenção e tratamento do tabagismo: uma vivência acadêmica de enfermagem. Cogitare Enferm. 2007;12(2):248-52.

3. Freitas MC, Mendes MMR. Chronic health conditions in adults: concept analysis. Rev. Latino-Am. Enfermagem. 2007;15(4):590-7.

4. Araújo AJ, Menezes AMB, Dórea AJPS, Torres BS, Viegas CAA, Silva CAR, et al. Diretrizes para Cessação do Tabagismo. J Bras Pneumol 2004; 30 suppl. 2:1-76.

5. World Health Organization-WHO [Homepage on the internet]. Geneva: WHO; 2008 [acesso $08 \mathrm{dez}$ 2009]. WHO Report on the Global Tobacco Epidemic The global tobacco crisis. Disponível em: http://www. who.int/tobacco/mpower/mpower_report_tobacco_ crisis_2008.pdf.

6. Ministério do Planejamento, Orçamento e Gestão (BR). Instituto Brasileiro de Geografia e Estatística IBGE. Pesquisa Nacional por Amostra de Domicílios 2008

- Tabagismo. Rio de Janeiro (RJ): IBGE; 2009. 
7. Lei no 9294, de 15 de julho de 1996, a qual dispõe sobre a proibição do uso de derivados do tabaco, em recinto coletivo privado ou público. Brasília: Ministério da Saúde INdC; 2007.

8. Governo do Estado de São Paulo (BR). Lei antifumo. Lei no 13.541, de 7 de maio de 2009. Constituição Federal 2009 [acesso 03 maio 2010]; Disponível em: http://www.leiantifumo.sp.gov.br/portal.php/lei.

9. Echer IC, Luz AMH, Lucena AF, Motta GC, Goldim JR, Menna Barreto SS. A contribuição de restrições sociais ao fumo para o abandono do tabagismo. Rev Gauch Enferm. 2008;29(4):520-7.

10. Marques ACPR, Campana A, Gigliotti AP, Lourenço MTC, Ferreira MP, Laranjeira R. Consenso sobre o tratamento da dependência de nicotina. Rev Bras Psiquiatr dez 2001; 23(4):200-14.

11. Knorst MM, Chiesa D, Krumel C, Mezzomo KM, Franciscatto A. Smoking prevalence among healthcare employees. Chest. 2004;126(4):867.

12. Fagerström KO, Schneider NG. Measuring nicotine dependence: areview of the Fagerström Tolerance Questionnaire. J Behav Med. 1989;12:159-82.

13. Nazareth CAL, Souza LA, Cardoso CB, Campos ENB. Frequência do tabagismo no ambiente hospitalar. HU Rev 2008;34(4):257-62.

14. Ministério da Saúde (BR). Porque se fuma e porque se deixa de fumar - Uma educação para a saúde criativa. Brasília: MS; 2004. [acesso 23 jun 2007]. Disponível em: www.anti-tabagismo.odline.com/default.jsp?id_ conteudo=6\&id_capitulo=04.01.01.

15. Barros MVG, Nahas MV. Health risk behaviors, health status self-assessment and stress perception among industrial workers. Rev Saude Publica. 2001;35(6):554-63.

16. Mirra AP, Pereira IMTB, Souza JMP, Stewien GTM, Morais MA, Valenchic DMO, et al. Tabagismo em Funcionários de dois Centros de Saúde Escolas de São Paulo. Rev Soc Bras Câncer 2004;1(1):22-6.

17. Nozawa D, Franken RA, Ribeiro KCB, Pereira AC, Sprovieri SRS, Golin V. Estudo comparativo entre pacientes infartados fumantes, ex-fumantes e nãofumantes. Arq Bras Cardiol. 2003;81(6):589-91.

18. Silva LM, Lacerda JFA, Araújo EC, Cavalcanti AMTS. Prevalência do tabagismo entre profissionais de saúde. Rev Enferm UFPE On Line. 2008;2(1):112-20.

19. Stramari LM, Kurtz M, Silva LCC. Prevalência e fatores associados ao tabagismo em estudantes de medicina de uma universidade em Passo Fundo. J Bras Pneumol. 2009;35(5): 442-8.
20. Martínez-Mantilla JA, Amaya-Naranjo W, Campillo HA, Díaz-Martínez LA, Campo-Arias A. Daily cigarettesmoking among colombian high school students: gender related psychosocial factors. Rev. Latino-Am. Enfermagem. 2008;16(5):903-7.

21. Echer IC, Barreto SSM. Determination and support as successful factors for smoking cessation. Rev. LatinoAm. Enfermagem. 2008 junho;16(3):445-51.
Received: Sep. $2^{\text {nd }} 2010$

Accepted: Nov. 22 2010 